\title{
Eros as godsdiens (of die religieuse viering van seks) ${ }^{1}$
}

\author{
Eben Scheffler \\ Departement Ou Testament en ou Nabye Oosterse Studies \\ Universiteit van Suid-Afrika
}

\begin{abstract}
Eros as religion (or the religious celebration of sex)

This article unashamedly argues for the positive value of sexuality and its profound religious dimensions. A stance is taken that goes beyond moralizing and ethicizing. The relationship in the Bible between eros and religion is explored by referring to the sexual image of God in Genesis 1:26-27, the religious dimension of the book of Song of Songs and Jesus' stance in contrast with that of Paul. Through religion humans' sexual experience should be enhanced in stead of being suppressed. Society should be sexualized.
\end{abstract}

How wonderful sex can be,

when men keep it powerful and sacred, and it fills the world!

Like sunshine through and through one!

D H Lawrence

\section{INLEIDING: TEEN ONVANPASTE VROOMHEID}

As seks ter sprake kom is baie van God se volgelinge vromer as Hy of Sy. Daarenteen wil hierdie bydrae onbeskaamd die erotiese religieus vier. Dit

\footnotetext{
${ }^{1}$ Opgedra aan Otto.

Watter kaart of watter ster sal ek jou wys om veilig deur die grysland heen te reis? Sal ek van 'n God praat wat verdoem, van Christus, en die Tien Gebooie noem? Voorlopig dan, maar onthou altyd aan jou dade grens 'n ewigheid; gee sin aan voorgeslagte deur die eeue heen, besef jy is ' $n$ vegter weer van die begin, alleen; en mag die Suiderkruis en Negesterre witter as die stedeligte in jou siel bly skitter.
} 


\section{Eros as godsdiens (of die religieuse viering van seks)}

neem direk standpunt in teen enige poging wat die seksuele degradeer as sou dit die "vleeslike" bestaan van die mens verteenwoordig in teenstelling met die "geestelike". Inteendeel, dit huldig die standpunt dat die seksuele juis religieus is en dat die viering van die seksuele 'n religieuse viering is. Die degradering van die seksuele wat so dikwels in religieuse kringe gebeur (dikwels met die Bybel in die hand), is juis onreligieus, onchristelik en demonies.

Baie is al geskryf oor seks en godsiens waarin oor die verhouding tussen seks en godsdiens of die Bybel besin word (bv Kroeze 1970:96-103; Nelson \& Longfellow 1994:71-114). ${ }^{2}$ Die seksuele en die religieuse word dan gesien as aparte lewensterreine of dimensies van die mens se lewe. Die godsdiens word heel vroom beskou as die belangrikste dimensie, want diens aan God (of die mens se siening van sy eie lewe in die lig van die ewige of goddelike) verteenwoordig daardie dimensie van die mens wat die stelreëls bevat in die lig waarvan die ander dimensies (bv die sosiale, politiese, ekonomiese en die seksuele, ens) beoordeel word.

Wanneer die religieuse só gesien word as die sogenaamde diens aan God wat probeer fokus op 'n bo-aardse werklikheid in 'n poging om van die hier en nou en konkrete van hierdie aardse werklikheid te ontsnap, neem God as die groot Reguleerder 'n hoofsaaklik etiek-verskaffende funksie in die mens se lewe in. Hy of Sy (in so 'n siening meesal Hy) word dan nie beleef of ervaar nie, maar hoofsaaklik gevrees. Ongelukkig funksioneer die groot wêreldgodsdienste (bv Christendom, Islam, Judaïsme en Hindoeïsme grotendeels op hierdie vlak, en soms ook die Boeddhisme en meer moderne religieuse bewegings wat klem lê op spiritualiteit (bv strominge in die New Age Beweging, vgl ook Wilber 2000:499-506).

In so 'n situasie kom die seksuele of erotiese bedroë daarvan af en speel dit tweede viool as verteenwoordigend van die mens se "laer drifte" en aardse drange wat wesenlik "sondig" is. Selfs al word seks verduur binne die voorgeskrewe ruimte van die huwelik, word dit steeds beskou as van 'n "laer aard" as die sogenaamde spirituele.

Intussen is die teendeel waar. As ons God as die skepper van die wêreld en onsself erken, moet ons terselfdertyd die ooglopende feit erken dat ons deur middel van die seksuele vereniging tussen man en vrou geskep is. Ons is die produk van die seksuele. Natuurlik weet ons almal dit, maar ooievaar- en bobbejaan-in-die-berg-stories is 'n teken van die feit dat ons die seksuele aard van ons oorsprong onder die mat probeer vee en ontken. Die

\footnotetext{
${ }^{2}$ Terwyl die resente publikasie van Vos \& Human (2007:89-204) verskeie relevante bydraes bevat waarin verskeie aspekte van seksualiteit positief in die lig van die Bybel beoordeel word, bevat die bundel ongelukkig geen bydra wat die wesenlike eenheid tussen godsdiens en seksualiteit ontgin nie.
} 
uitdrukking "in sonde ontvang en gebore" is ook 'n poging om die seksuele te degradeer, indien dit dan nie ontken word nie.

Soos reeds gesê, leef ons eintlik in twee wêrelde ten opsigte van die seksuele. Aan die een kant weet ons dat dit aan die grond van ons bestaan lê en dus wesenlik deel van ons menswees is, maar aan die ander kant staan ons ongelukkig in 'n godsdienstige tradisie waarin die erotiese oor 'n tydperk van duisende jare swart gesmeer is, onderdruk is, of hoogstens as minder edel erken of dus bloot "toegelaat" is (vir 'n oorsig van hierdie negatiewe houding, vgl Janson 1995; Carr 2003:5-8). Ten einde ons van hierdie situasie te bevry, is 'n besinning rondom verskeie aspekte wat vir hierdie toestand van sake verantwoordelik is, dus nodig. Oor die filosofiese besinning hieroor (wat die skeiding tussen die religieuse en seksuele in terme van Plato se filosofie verklaar) word - as gevolg van beperkte ruimte - nie hier ingegaan nie. In wat volg, sal egter gepoog word om nie net op die negatiewe te fokus nie, maar om die positiewe religieuse viering van die erotiese steeds binne die gesigsveld te hou.

\section{VERBY MORALISERING EN ETISERING}

Die gewone diskoers oor seks en godsdiens gaan gewoonlik oor morele vrae (kyk bv Kretzschmar 2001:27-38; Thielicke 1964). Meestal wanneer oor seks en godsdiens in een asem gepraat word, is dit wanneer seksuele gedrag vanuit godsdienstige perspektief beoordeel en (veral veroordeel) word. Wat is normaal? Wat mag mens doen? Hoe moet mens jouself beheer? Is seks voor die huwelik sonde? Is pornografie sonde? Is orale seks normaal? Wat van masturbasie? Is poligamie Bybels en dus toelaatbaar? Wat van homoseksualiteit? Wanneer is mens aan seks verslaaf? Is geboortebeperking toelaatbaar? Moet VIGSpasiënte kondome gebruik? Moet prostitusie gewettig word? Is VIGS God se straf op die mensdom se seksuele uitspattigheid?

Om die seksuele religieus te vier, beteken om verby hierdie en ander morele vrae van moets en moenies te beweeg. Daar waar die besinning rondom moets en moenies sig opdring, moet dit as 'n springplank gebruik word om weer eens by die religieuse viering van seksualiteit uit te kom.

Aangesien die seksuele ' $n$ groteske mag is wat mens wesenlik raak, is dit waar dat 'n onvanpaste gebruik daarvan die vermoë het om groot menslike pyn en leed te veroorsaak. Bogenoemde vrae is dus nie ongeldig nie, maar dit sou uiters tragies wees indien (en ongelukkig gebeur dit meer dikwels as minder) hierdie vrae (en 'n legio derglikes) die totaliteit van die besinning oor die verhouding tussen godsdiens en die seksuele uitmaak. Die kern van die wesenlike eenheidsrelasie tussen die erotiese en die religieuse word so gemis. Die skeidsmuur tussen die seksuele en die religieuse wat gebou word 


\section{Eros as godsdiens (of die religieuse viering van seks)}

met hierdie vrae (en die eindelose besinning daaroor) is op sigself gevaarlik en (by wyse van spreke) meer skadelik as die vermeende "sonde" wat dit probeer aanspreek.

Indien die eenheidsverhouding tussen die seksuele en die religieuse egter erken word, word bogenoemde vrae oorbodig. Dan funksioneer die seksuele op wat mens sou kon noem 'n "evangeliese" vlak. Dit werk soos Jesus se opsomming van die wet: indien liefde tot God en liefde tot die naaste deur die mens verinnerlik word, hoef daar eintlik nie meer besin te word oor valse getuienis, diefstal, egbreek en moord nie. Dan gaan dit nie meer oor die veroordeling of die vermyding van sulke aangeleenthede nie, maar oor die nastreef (sonder dwang en dus van harte) van die positief teenoorgestelde daarvan. In plaas van steel, sal mense uit vrye wil eerder vir ander gee; in plaas van valse getuienis, eerder goed praat van hulle (vgl Ef 4:28); in plaas van moor, veg vir die behoud van lewe; in plaas van egbreek en opbreek, die huwelik en liefdesverhoudings koester (o a met behulp van 'n gesonde sekslewe!).

'n Mens hoef nie (geïntimideer deur die verdraaide godsdienstige tradisie waaruit jy moontlik kom) skuldig te voel as jy die eenheid tussen die seksuele en die religieuse erken nie. Natuurlik loop mens die gevaar dat jy beskuldig sal word dat jy seks verafgod of vergoddelik. Dit is egter in beginsel onmoontlik, want mens kan nie verafgod of vergoddelik wat reeds goddelik is nie. Die probleem lê nie hier by die vergoddeliking van seks nie, maar by die "ontgoddelikking" of profanisering daarvan. Want seks is heilig en om dit te ontken is siek, onheilig en abnormaal.

'n Voorbeeld van die valse onderskeid tussen seks en godsdiens vind ons in die eens gesaghebbende en wyderkende boek van Nygren, getiteld Agape en eros (1969). Uitgaande van die vermeende Griekse betekenis van die woorde eros (= die seksuele drif) en agape (= onbaatsugtige liefde), maak Nygren dan 'n onderskeid tussen die seksuele wat op 'n laer vlak lê en die liefde wat op 'n meer gewenste vlak lê. Om na seksuele omgang te verwys as "liefde maak" sou dan 'n wanbegrip van liefde en 'n onregmatige skaking van die term verteenwoordig. Intussen is dit juis wat seks behoort te wees en is "liefde maak" 'n baie beter beskrywing van seksuele omgang as "saamslaap" of bloot "om seks te hê". Weer eens: die probleem lê nie by die gebruik van die term "liefde maak" nie, maar by die neiging (soos by Nygren en ander) om die seksuele los van liefde te sien en dus te degradeer. Wat Nygren se standpunt des te erger maak, is dat hy 'n twintigste-eeuse Nuwe Testamentikus is wat sy standpunt as Bybels aanbied en daarmee die droewige verhouding wat die Christelike kerk deur die eeue heen ten opsigte van die seksuele gehad het, kontinueer. Om Nygren vanuit die Bybel te weerlê sou maklik wees indien sodanige bewysvoering vir andersins voor-die- 
hand-liggende insigte vereis word. Die Efesiërbriefskrywer het dit reg gehad toe hy in Efesiërs 6 na die liefde tussen man en vrou verwys het met die begrip agape. Die hele evangeliese boodskap word daar ingespan om die man-vrou verhouding te defineer, en so word die man-vrouverhouding eintlik deel van die evangelie. In Efesiers 6:28-32 (kennelik nie deur Paulus geskryf nie!) funksioneer die seksuele en godsdiens duidelik as 'n onlosmaaklike eenheid:

So behoort mans hulle vroue lief te hê soos hulle eie liggame .... Daarom sal die man sy vader en moeder verlaat en sy vrou aankleef en hulle twee sal een vlees $^{3}$ word (Gen 2:24). Hierdie misterie is groot en ek sê dit met die oog op die gemeente. Maar ook met die oog op julle: elkeen van julle moet sy vrou liefhê net soos homself.

So gesien is seksualiteit inderdaad 'n konkrete bewys dat liefde bestaan.

'n Bekende en gewilde boekie van die sielkundige Erich Fromm moet ook in hierdie verband genoem word. In The art of loving (1957:37-71) maak Fromm die onderskeid tussen verskeie vorme van liefde. Hy onderskei tussen liefde tussen ouers en kinders, liefde tussen broers en susters, moederlike liefde, erotiese liefde, selfliefde en liefde tot God. Deurdat hy alles in een boek behandel, skep hy die indruk dat al hierdie vorme van liefde dimensies van die groot begrip "liefde", is. Indien mens die boek lees, is dit ongelukkig juis nie so nie. Veral die erotiese staan soms in teenstelling met moederlike liefde of liefde tot God. Dít terwyl siekundiges al lankal raakgesien het dat daar 'n erotiese konnotasie bestaan in die liefde van 'n ma vir haar kind (bv as die baba aan die bors drink). Deurdat Fromm die erotiese ook uitsluitlik of hoofsaaklik in term van die fisiese definieer, word die kenmerke wat dit met liefde tot God in gemeen het, onderspeel (bv totale aanvaarding, teerhartigheid, sorg en volkome oorgawe).

'n Gesonder siening sou wees om die bestaan (want ons bestaan!) van liefde te erken as 'n eenheidskonsep, wat in die praktyk nie verskillende vorme nie, maar verskillende wel fokuspunte aanneem. Sê die skrywer van die Johannesbriewe dan nie dat God liefde is en dat diegene wat liefde het, in God bly nie? (1 Joh 4:7-8). Diegene wat die bestaan van God ontken (sogenaamde ateïste), maar steeds in die wye sin van die woord liefhet, hoef ons dus nie te ontstel nie, want hulle ontken nie God soos wat Hy of Sy werklik is nie, maar die verdraaide drogbeeld van Hom of Haar wat hoogheilige aansprake op geloof maak, maar in die praktyk dit loënstraf (deur bv die brandstapels van eksklusiwiteit en veroordelende houdings).

\footnotetext{
${ }^{3}$ Die 1983-vertaling "en hulle sal een wees" is duidelik eufemisties en 'n verkapte ontkenning van die seksuele eksplisietheid van Genesis 2:24.
} 


\section{Eros as godsdiens (of die religieuse viering van seks)}

Beteken bostaande dat 'n kritiese houding nooit ingeneem kan of moet word nie? Allermins! Kritiek is veral nodig teen die duiwel van liefdeloosheid (en seksloosheid) wat immer rondloop en soek waar hy die seksuele kan verdag maak en die liefde kan verslind. Hierdie duiwel moet met alle mag bestry word, veral waar hy hom omhul met geveinsde hoogheilige "reinheid" en "suiwere" geloof.

Beteken bostaande verder dat, indien 'n mens jou seksualiteit volledig erken en verby moralisering en etisering beweeg jy nie (uit vrees dat jy dalk 'n veroordelende houding gaan hê) oor die seksueel-etiese vrae hierbo 'n mening gaan hê nie? Natuurlik nie. Jy gaan juis 'n mening hê, maar nie 'n mening wat uit reëlboekies of uit die Bybel-gereduseer-tot-'n-reëlboekie gemotiveer word nie, maar 'n siening wat jy vir jouself vanuit jouself, uit die bron van die seksuele as religieuse wat in jou is, ontwikkel. Jy het dan juis 'n deurdagte standpunt (wat kan verder ontwikkel en verander) en nie bloot 'n oorgeneemde reël nie.

Kom ons pas wat so pas gesê is op van die voorbeelde toe. Die antwoorde kan kennelik nie bestaan in 'n "ja" vir dit en "nee" vir dat nie, of dat sekere gedrag "normaal" of "abnormaal" is nie, want dan val ons weer in die strik dat ons stelreëls voorskryf wat los van 'n mens in die lug hang en nie deur elkeen vir sigself vanuit sigself (met die erotiese as godsdiens as rigsnoer) vir 'n bepaalde tyd en situasie ontwikkel is nie. Hoe spreek ons dan die vraagstukke aan? Kennelik nie deur apodiktiese voorskrifte nie. 'n Beter weg, met die kriterium van die liefde (1 Kor 12:31), sou kon wees deur vrae te vra en die moontlikhede van verskeie opsies te ondersoek.

\subsection{Oor voorhuwelikse seks (as voorbeeld)}

Diegene wat voorhuwelikse seks summier veroordeel as sonde reduseer seksualiteit tot penetrasie. Indien mens met Bybelteksies wil werk het elke ketter sekerlik sy letter. Deuteronomium 22:13-30 veroordeel sogenaamde voorhuwelikse seks, maar Hooglied besing seksualiteit in sy totaliteit sonder vermelding van die huwelik. Tradisioneel word dit deur die Christelike tradisie veroordeel, maar selfs uit Christelike kringe word soms beweer dat voorhuwelikse seks met die oog op minder egskeidings eintlik gewens is (vgl die argumente by Kretzschmar 2001:72; vgl ook Müller 2007:372-382).

In die Bybel is daar ' $n$ kaleidoskopiese verskeidenheid sieninge oor die seksuele wat wissel van vrywillige selfkastrering (Matt 19:12) met die oog op die koninkryk van God (iets wat in die selibaat verword het tot 'n wet) tot die ahuwelikse perspektief van die boek Hooglied. Hierdie verskeidenheid sieninge onderstreep juis die standpunt dat sieninge oor hierdie aangeleenthede kontingent behoort te wees, nou gekoppel aan spesifieke mense in spesifieke 
situasies. Voordat 'n spesifieke gedrag dus summier veroordeel word, is dit meer aangewese om die spesifieke situasie te bekyk. Indien outentieke seks tussen mense plaasvind, vind dit plaas as 'n godsdienstige gebeure. Gaan dit gepaard met deernis, totale aanvaarding, teerhartigheid, sorg en volkome oorgawe? Is seksuele omgang wat op hierdie wyse voor die huwelik plaasvind, nie beter as die funksionering van seksualiteit binne die huwelik as 'n vanselfsprekende "huweliksreg", manipulerende magsmiddel of bloot fisieke daad nie? Tog interessant dat in die Christelike (en ander) tradisies daar dikwels meer bekommernis heers oor die wanneer van die seksuele daad as oor die kwaliteit (= religieuse aard) daarvan. Kerklui, onderwysers, ouers en ander agente van 'n superego-gedomineerde samelewing is dikwels meer bekommerd dat mense dit dalk buite die huwelik doen, as dat hulle dit binne die huwelik met liefde of hoegenaamd doen. Miskien moet dit vir eens hard en duidelik gese word: Voorhuwelikse seksualiteit is nie die noodwendige oorsaak van egskeidngs nie, maar eerder die afwesigheid van goeie seks (of religieuse eros of heilige seks, of kortom: liefde, God) binne die huwelik.

Impliseer wat hier gesê is, dat voorhuwelikse seksualiteit die ideaal is of selfs verpligtend behoort te wees? Indien seksualiteit slegs gesien word as die fisiese en veral penetrasie, sou die antwoord nee wees. Indien seksualiteit gesien word as 'n ruimer liefdevolle religeuse gebeure (wat selfs sonder penetrasie kan plaasvind), is dit steeds nie verpligtend nie, maar voor-diehand-liggend. Dit is tog net in "matchmaker"-huwelike dat die erotiese nie ter sprake is met die sluiting van die huwelik nie. En daarvan het die moderne westerse samelewing reeds lankal al afskeid geneem.

Elkeen moet hom- of haarself afvra: wat is in my situasie van pas? Wat is in mý situasie die uitlewing van deernis, totale aanvaarding, teerhartigheid, sorg en volkome oorgawe? Pleks daarvan om voorhuwelikse seks te verdoem, te verban of te probeer uitroei, behoort dit tot die pastorale taak van predikante, sielkundiges en seksuele beraders om eerder mense aan te moedig om hulle seksualiteit (binne of buite die huwelik) religieus te beleef en uit te leef. Daarom behoort diegene wat in elk geval saambly, aangemoedig word om dit in liefde te doen en hulle seksuele verhouding steeds religieus te interpreteer, eerder as wat hulle reken dat omdat hulle nou volgens die samelewing se waardes in elk geval in sonde leef, hulle seksuele verhouding niks meer met die religieuse te doen het nie. So ook behoort getroudes nie maar net aan hulle lot oorgelaat te word so lank hulle maar net ten alle koste getroud bly nie, maar moet hulle seksuele verhouding steeds tot groter hoogtes aangemoedig en gestimuleer word. Juis dit sou die evangeliese opdrag van die kerk wees (teenoor laasgenoemde se swak "track record" van die verlede). Juis dit voorkom egskeidings. Baie keer sê die superego-agente: 


\section{Eros as godsdiens (of die religieuse viering van seks)}

"Moet tog net nie skei nie, al is die seksuele afwesig, veral ter wille van die kinders." Maar niks is so goed vir kinders en maak hulle so gelukkig as om so veel as moontlik hulle ouers in omhelsing te sien nie. Kerklui en beraders moet hulle dus eerder beywer vir die bevordering van seks binne die huwelik (waaraan hulle dalk iets kan doen) as om voorhuwelikse seks te beveg (wat hulle helaas nie kan keer nie).

\subsection{Oor masturbasie (as nog 'n voorbeeld)}

Wat van masturbasie? In Christelike kringe is dit in die verlede dikwels veroordeel as onkuisheid en onreinheid en sekere Bybelse tekste (soos bv oor Onan, vgl Gen 38:9) is valslik daaraan gekoppel, selfs nadat die Kinseyverslag in die vyftiger jare gekom het met gegewens dat feitlik $100 \%$ van alle mans dit doen (selfs die veroordelers) en $70 \%$ vrouens. Natuurlik is die feitlik $100 \%$ van mans verklaarbaar. Dit is 'n biologiese wet dat die man se saad wat opbou, gestort moet word. Indien dit nie by wyse van masturbasie geskied nie, dan gebeur dit onwillekeurig tydens 'n erotiese droom. Plaas daarvan dat God geprys word vir die wonder van die natuur wat so werk, word masturbasie egter steeds dikwels in religieuse kringe veroordeel of gedegradeer en word skuldgevoelens daar rondom opgewek. Intussen is dit 'n wonderlike hulpmiddel vir ongetroudes of getroudes met seksuele frustrasie (bv tydens swangerskap en geboorte, of binne "verkoelde" verhoudings). Dat masturbasie sonde sou wees, omdat dit selfsugtig of selfgerig sou wees is 'n mite, want om jou eie liggaam nie te waardeer nie, is om ondankbaar teen God te wees. Juis die fantasering oor seks en die seksuele selfekspressie deur middel van masturbasie is noodsaaklik in die seksuele volwassewording met die oog op 'n gesonde volwasse sekslewe. Die probleem hier is nie die masturbeerders nie, maar die skynvromes wat pakke op mense se rûens laai wat hulle nie kan dra nie en sodoende die grondslag lê vir distorte seksuele opvattings wat weer aanleiding gee tot seksueel onvervulde huwelike, wat weer aanleidings gee tot egskeidings.

Weer eens moet die vraag gevra word: wat dra by tot liefde, deernis en sorg? Die veroordeling van masturbasie as teen die mens se natuur, is nie net ongesond nie, maar liefdeloos, onchristelik en demonies. Eerder moet jongmense (en selfs ouer mense wie se partners hulle ontval het) aangemoedig word om die erotiese opwelling in hulle liggame religieus te interpreteer, om dit te sien as deel van liefde in die breër sin en om God daarvoor te dank.

Nog iets oor masturbasie by vroue. Gewoonlik is die $30 \%$ vroue wat nooit masturbeer nie (dikwels as gevolg van manipulering deur oorbekommerde neorotiese en ongeligte moeders) diegene wat later ly aan 
die (gelukkig meesal geneesbare) siekte van seksuele koudheid (frigiditeit). En hoe behandel seksuele beraders meesal frigiditeit? Deur vrouens te leer om eers te masturbeer, om sodoende hulle eie seksualiteit te aanvaar. Hierdeur is menige huwelik al gered en egskeidings voorkom (met liefde, deernis en sorg die resultaat vir alle partye). Weer eens lê die seksuele en religieuse op 'n kontinuum en staan sekslose godsdiens wat God se gawes veroordeel, as valse godsdiens ontbloot.

Wat pas oor masturbasie gesê is, klink na 'n ongekwalifiseerde ja daarvoor, wat (hoewel positief) na apodiktiese moralisering kan klink. Inderdaad sou daar situasies kon voorkom dat masturbasie ongewens is. Die grootste voorbeeld sou wees indien mens dit in plaas van seksuele omgang met jou lewenspartner verkies en sodoende jou partner tart, afpers of seermaak. Dan dien dit haat en liefdesloosheid en nie deernis en sorg nie. Dan funksioneer dit goddeloos en nie goddelik nie.

Voorhuwelikse seks en masturbasie is hier bespreek as voorbeelde oor hoe denke oor sogenaamde "etiese probleme" kan funksioneer as springplank om die seksuele religieus te vier. Om op alle vraagstukke ${ }^{4}$ hier in te gaan sou maklik weer kon lei tot moralisering, wat nie die doel hier is nie.

\section{EROS AS GODSDIENS IN DIE BYBEL}

Omdat die Bybel as basisdokument in ons kultuur funksioneer en veral deur kerklui gebruik word om die seksuele te degradeer, is 'n herwaardering van sekere gedeeltes uit die Bybel van pas. Sodoende kan diegene wat hulle eie seksualiteit wil erken en religieus wil vier, weet dat hulle daardeur nie handel teen die die Bybel as sodanig is nie, maar teen 'n verengde en verdraaide siening oor die Bybel. Meer nog: Die positiewe besinning rondom sekere Bybelgedeeltes kan mens juis help om tot seksuele vryheid te kom en die seksuele godsdienstig te vier, ten spyte van die aanslae van veroordelende morele sedebewakers en skynvromes. In wat volg, word seksualiteit in die Bybel geensins volledig bespreek nie, maar word gekonsentreer op aspekte wat die motief van eros as godsdiens ondersteun.

\subsection{Die seksuele beeld van God}

Ongelooflik baie is al geskryf oor die mens as imago Dei (beeld van God) na aanleiding van Genesis 1:26-27. Min is egter al geskryf oor die seksuele

\footnotetext{
4 ' $\mathrm{B}$ Brandende vraagstuk vandag is die debat rondom homoseksualiteit waarop daar nie hier gefokus word nie (vgl die positiewe bydraes van Kretzschmar 2001:108-135; Otto 2007:5866; Du Toit 2007:161-171 en Steyn 2007:172-204). Wat poligamie en poliandrie betref, vgl die insiggewende proefskrif van Dorey (2003).
} 


\section{Eros as godsdiens (of die religieuse viering van seks)}

implikasies van die teks en wat dit vir die verhouding tussen die seksuele en die religieuse inhou.

Volgens die Genesis 1-skeppingsverhaal het God die mense en diere op die sesde dag geskape. 'n Belangrike motief van Genesis 1:24-31 is die mens se ekologiese verantwoordelikheid, wat gewoonlik baie (en geregverdigde) aandag in die besinning rondom hierdie teks ontvang, soveel só dat die seksuele implikasies van die idee van die mens as beeld van God onderspeel word. In Genesis 1:26 besluit God: "Laat ons mense maak na ons beeld, na ons gelykenis ..." Dan volg die heersmotief. In Genesis 1:27 word in die derde persoon oor God berig dat hy sy voorneme uitgevoer het. Genesis $1: 27$ en 28a bevat egter motiewe wat belangrik is vir die outeur se siening oor God en seksualiteit:

So het God die mens geskape na sy eie beeld
na die beeld van God het hy hom geskape
manlik en vroulik het hy hulle geskape;
en God het hulle geseën en vir hulle gesê:
Wees vrugbaar en vermeerder en vul die aarde ...

In Genesis 1:26 word by die term "ons beeld" ook die term "ons gelykenis" toegevoeg (wat nie gebeur in vers 27 nie). Die term "ons gelykenis" beteken eenvoudig "soos ons" en verduidelik die imago Dei. Dat die mens volgens die teks "soos" God is, beteken nie dat die mens soos God lyk nie (van beeldvoorstelllings van God wil die Oud-Israelitiese denke juis wegkom - vgl Eks 20:1). Wat wel bedoel word, word in verse 26-30 verduidelik, en inderdaad staan die idee van heers oor die aarde (en veral die diereryk) voorop. Vers 27 verraai egter 'n ander belangrike aspek van die konsep "beeld van God".

Volgens vers 27 volg die uitdrukking "manlik en vroulik het hy hulle geskape" direk op die stelling dat God die mens na sy beeld geskape het. As sodanig verduidelik dit ook die uitspraak. "Manlik en vroulik" saam vorm die beeld van God, nie net die man alleen (soos wat dikswels gedink word nie). In God se beeld, in sy natuur, dit wil sê hoe Hy of Sy is, lê daar dus manlikheid en vroulikheid. ${ }^{5}$

Meer nog: die Hebreeuse woordkeuse onderstreep die seksuele aard van wat met manlikheid en vroulikheid bedoel word. Die gebruiklike Hebreeuse woorde vir man en vrou is "isj" en "isja" en word byvoorbeeld in die tweede skeppingsverhaal in Genesis 2:21-24 (waar daar 'n volgorde in die

\footnotetext{
${ }^{5}$ Weliswaar is hierdie idee sekerlik nie sekere feministe (wie God as uitsluitlik vroulik wil sien uit reaksie teen jarelange manlike onderdrukking) se droom nie, maar dit is moontlik wel 'n vrugbare gedagte vir mans en vrouens wat saam by feminisme en patriargalisme verby is ( $\mathrm{vgl}$ in hierdie verband die insiggewende boek van Landman 1999:23-26)
} 
skepping van die geslagte is en waar nie van die man en vrou as beeld van God sprake is nie) gebruik. In Genesis 1:27 (waar man en vrou saam beeld van God is) word van die gebruiklike terme afgewyk en die Hebreeuse terme "zakar" en "neqeba" gebruik. Nou is die mooie dat hierdie terme die seksuele beklemtoon op 'n heel eksplisiete wyse. Die term "zakar" (=manlik) beteken oorspronklik "dit wat regopstaan" en "neqeba" beteken "holte". Saam vorm dit die beeld van God! Hierdie seksuele konnotasie word nog verder onderstreep in vers 28a waar daar onmiddellik verwys word na die vrugbaarheid van man en vrou en hulle vermeerdering. Dit is dus duidelik dat die seksuele en religieuse hier nie net na aanmekaar kom nie, maar as 't ware oorvleuel. Nie net die man is die beeld van God nie, ook nie man en vrou as bloot mense nie, maar man en vrou in hulle seksuele vereniging. God is nie manlik of vroulik nie, maar manlik én vroulik (veral wanneer hulle liefde maak).

God is dus alles behalwe a-seksueel. In die godsdiensgeskiedenis van Oud-Israel, in die Jodedom en in die Christendom is God wel al hoe meer "ontseksualiseer", maar diegene wat hulle seksualiteit religieus wil vier kan die bykomende genoegdoening hê dat hulle (minstens wat Genesis 1:27 betref) nie teen die Bybel dink nie.

\subsection{Oor Hooglied se religieuse aard}

Hooglied is die boek in die Bybel waaroor die meeste kommentare verskyn het. Indien dit sou wees omdat die boekie oor erotiek handel moet dit beslis op die onbewuste vlak lê by die kommentatore, aangesien die meeste kommentare nie Hooglied se seksualiteit besing en vier nie, maar juis probeer (weg)verklaar hoekom so 'n "profane" boek wat oor seks handel, in die Bybel tussen al die ander "heilige" boeke is. Die meeste kommentare het dus deur die eeue heen gestaan in die teken van die allegorie, wat die liefde tussen minnaars wat in Hooglied besing word nie interpreteer as ' $n$ viering van die seksuele nie, maar as verwysende na die verhouding tussen God en Israel of tussen Christus en sy kerk (oorsig by Pope 1977:179-183). Hierdeur word Hooglied op sy kop gekeer binne 'n hermeneutiese raamwerk waar die seksuele teenoor die religieuse staan. Volgens die allegoriese interpretasie gaan dit nie in Hooglied om die seksuele nie, maar oor die a-seksuelereligieuse, nie om seksuele liefde nie, maar om vermeende "heilige, goddelike liefde".

Natuurlik is dit so dat elders in die Bybel die verhouding tussen God en Israel of tussen Christus en die kerk wel in terme van die man-vrouverhouding uitgedruk word. In beide gevalle (Hos 1-3 en Ef 6) is dit egter duidelik uit die teks afleibaar. In Hosea 1:2 kla God dat sy volk ontrou aan hom geword het en soos 'n "hoer" agter ander gode aanloop. In Efesiërs 6 


\section{Eros as godsdiens (of die religieuse viering van seks)}

betrek die briefskrywer die een-vlees-wording van man en vrou as "diepe misterie" op die gemeente. In hierdie tekste word die seksuele dus nie gedegradeer of ontken nie. Inteendeel, die religieuse kwaliteit daarvan word beklemtoon deurdat dit as metafore dien vir God se verhouding met sy mense.

Anders is die geval met die allegoriese interpretasie van Hooglied. Hooglied is seksueel uiters eksplisiet met openlike (a-huwelikse!) verwysings - nie net na die naakte manlike en vroulike liggaam nie, maar veral die seksuele organe (bv die vrou se borste en vagina), asook seksuele aktiwiteit (bv soene, seksuele danse, orale seks en koitus - vgl bv Hoogl 1:1; 7:1-10). Nêrens in die boek is daar ' $n$ aanduiding dat hierdie aspekte moet (weg)verklaar word in terme van God se verhouding met sy mense nie. Trouens, in die boek Hooglied is daar geen verwysing na God nie. Ook nie in Hooglied 8:6 waar verwys word na die (erotiese) liefde as 'n "vlam van die Here" nie. Hooglied 8:6 wil beklemtoon hoe sterk erotiese liefde is: soos die dood, soos 'n magtige vlam. As sodanig is dit wonderlik en feitlik onuitroeibaar. Maar selfs indien die Hebreeuse term in vers 6 (sjalhebetjah) na Jahwê sou verwys, staan dit geensins in die teken van 'n antigodsdienstige interpretasie van die seksuele soos by die allegorie nie. Inteendeel: seks is dan 'n vlam wat van die Here kom.

Die vraag kan gevra word of Hooglied nie so 'n sekulêre boek is dat dit glad nie met godsdiens in verband gebring kan word nie? Word die eerste wig tussen godsdiens en seks nie dalk juis in Hooglied geslaan nie? Afgesien van die feit dat 'n a-religieuse interpretasie van die werklikheid in die tyd van die boek se ontstaan feitlik ondenkbaar is, kan verskeie argumente hierteen genoem word (vgl ook Walsh 2000:187-116; Carr 2003:91-154).

Eerstens is Hooglied ingesluit in die Bybe/ wat in sy geheel 'n religieuse kanon verteenwoordig. Indien die mens se liggaam en al sy seksuele eienskappe daarin positief besing word, dan sou dit sekerlik die implikasie hê dat seksualiteit uit 'n religieuse oogpunt gekondoneer word. So betoog die bestaan van die boek Hooglied in die Bybel dus teen skynvromes wat seksualiteit wil afmaak as iets vuils of ongodsdienstig (of slegs binne die eng ruimte van die huwelik toelaatbaar).

Tweedens kan Hooglied slegs a-religieus geïnterpreteer word indien die kriterium vir godsdienstigheid is dat vir elke saak om godsdienstig te wees, God se naam eksplisiet daar moet by staan. In Hooglied speel die vrye natuur 'n groot rol as lokus waarin die seksuele sig voltrek (naas bv die slaapkamer van die koning). Hierdie natuur is God se skepping in sy ongereptheid en 'n siening van godsdiens wat altyd menslike woorde daarby vereis, vereng dit juis. Inteendeel, mens sou kon sê dat Hooglied juis die tradisionele religieuse 
woorde verminder sodat die mens sonder God (of die dogters van Jerusalem) as spelbreker die seksuele kan geniet. ${ }^{6}$ Juis hierin lê 'n besondere religieuse aspek van die seksuele.

Derdens besing Hooglied seksualiteit as liefde. Die term wat vir "liefhê" gebruik word is die gebruiklike (ahab), wat ook gebruik word as van liefde tot God en tot die medemens gepraat word. Alhoewel eksplisiet, word seksualiteit in Hooglied dus nie gebanaliseer nie. Die Hoogliedskrywer sien dus nie die seksuele as apart van ander liefdes nie. Inteendeel, die seksuele vind in harmonie met ander verhoudings plaas. Die ouers word nie beleef as veroordelende superego-figure nie, maar word dikwels na verwys gedurende die liefdesspel $(3: 4 ; 8: 5)$. Plaas daarvan om die ouerhuis te vermy, is dit die meisie se begeerte om haar minnaar na haar ouerhuis te neem om daar deur haar minnaar ingewy te word in die fynste liefdeskunsies (8:2). Juis hierdeur word die ouers geëer (vgl Eks 20:3) en verhoog die religieuse die seksuele kwaliteit. Ouers wat dus gedurigdeur hulle kinders se seksualiteit ontken of probeer tem, tree dus juis onreligieus op.

Vierdens gebruik die boek Hooglied verskeie religieuse terme en beelde. Daar word telkens na die godstad, Jerusalem, verwys wanneer die vroue van Jerusalem versoek word om nie die verliefdes te steur terwyl hulle liefde maak nie. Dieselfde geld ten opsigte van die Dawidstoring in die stad en na offerplekke. Weliswaar is daar geen direkte koppeling met byvoorbeeld die religieuse dogmas, kultus, "verbondsreligie" of die heilsgeskiedenis nie. Juis dít kommunikeer binne die breër godsdienstige konteks van die dag dat die seksuele soos wat dit is, op sigself religieus is en deel van die konsep van liefde in die wydste sin van die woord. Deur die seksuele heel voor-die-handliggend en "sekulêr" uit te beeld, verhoed die boek Hooglied juis dat daar deur 'n suiwer tradisioneel-godsdienstige intepretasie van die boek 'n wig tussen godsdiens en die seksuele ingedryf word en dat die erotiese liefde tussen man en vrou uitgeskuif word as 'n "vleeslike" ongodsdienstige liefde wat nie opsigself religieus is nie.

Só gesien ondersteun die boek Hooglied dus die idee dat seks en godsdiens verlengstukke van mekaar is. Die liefde tussen die geslagte is deel van die goddelike liefde. Hierdie siening wat deur die boek Hooglied gekommunikeer word, sal egter vir vele te goed klink om waar te kan wees. Is dit nie alles fantasie wat nooit in die werklikheid gebeur nie? En indien dit sou

\footnotetext{
${ }^{6}$ In ou vertalings (ongelukkig ook die NAB) is die tekste oor die dogters van Jerusalem (wat dan nie die liefde "moet opwek voor dit die liefde behaag nie", of "moet wakker maak en aanvuur voor die tyd daarvoor ryp is nie", $\mathrm{Hgl}$ 2:7;3:5) verkeerd vertaal om 'n dempende invloed op die seksuele uit te oefen. Die teendeel is waar: hulle word opgeroep om nie spelbrekers te wees in die minnaars se liefdesspel nie. Meer korrek is die Good Newsvertaling: "I am weak from passion. Promise me, women of Jerusalem, swear by the swift deer and the gazelles that you will not interrupt our love."
} 


\section{Eros as godsdiens (of die religieuse viering van seks)}

gebeur, dan gebeur dit nie met almal nie en beslis met sommiges nooit nie. Wat van onvervulde liefde? Wat van iemand wat nooit sukses het op seksuele gebied nie? Wat van liefde wat verkoel, huwelike wat misluk, liefde wat tot haat skif?

In 'n insiggewende artikel spreek David Clines (1995:94-121) hierdie probleem aan. Hy oordeel taamlik negatief oor die positiewe uitbeelding van seksualiteit in die boek Hooglied. Anders as die allegoriste is dit glad nie omdat hy die spesifiek seksuele aard van die boek wil ontken nie. Trouens, hy gaan so ver om te beweer dat die boek "sagte pornografie" is. As pornografie is dit skadelik, want pornografie is fantasie, seks wat slegs in die mens se verbeelding bestaan. Die werklikheid buite hierdie fantasie is heeltemal anders. Die boek Hooglied tower dus 'n paradysagtige wêreld aan die leser op wat indien hulle dit in die praktyk sou soek, hulle net hulle koppe sou stamp. Want die wêreld daarbuite is alles behalwe 'n paradys. Elkeen moet swoeg om 'n bestaan. Armoede, konflikte en vele ander vorme van lyding is alomteenwoordig. Dit is goed dat Clines ons hieraan herinner, want inderdaad is die lewe op aarde geen paradys nie. Hiermee hou die boek Hooglied ook self rekening as daar gepraat word oor die jakkalsies wat die wingerd verniel, of as die meisie aangeval word wanneer sy na haar geliefde soek.

Om die boek Hooglied af te skryf op grond van die "fantastiese" (!) aard daarvan, is egter ook nie wenslik nie. Dit sou wees om die liefde af te skryf omdat daar haat en lyding in die wêreld is; om godsdiens af te skryf omdat alles nie volmaak is nie. Dat die wêreld vandag so oorbevolk is, is immers 'n direkte resultaat van die uitvoering van Genesis 1:27 se opdrag. Verder is dit 'n feit dat seksualiteit vandag deur baie mense geniet word (as rekreasie en nie as prokreasie nie), of minstens soms geniet word. Die feit dat dit nie meermale gebeur nie is minstens onder andere omdat mense die slagoffers is van verdraaide anti-seksuele pseudo-godsdienstige sienings, of omdat hulle verdraaide prioriteite het (deur bv besittings en roem hoër te ag as die liefde).

Verder speel die voyeuristiese, deels-fantastiese aard van die boek Hooglied (of enige seksuele fantasie) 'n uiters belangrike terapeutiese rol. Vir diegene wat ontdaan is aan die voorregte van die liefde, bied dit steeds hoop op die toekoms, of kan dit opsigself as fantasie geniet word. Dit is juis diegene wat slegs die negatiewe in die werklikheid raaksien wat bydra tot die nagatiewe ('n "self-fulfilling prophecy"), terwyl diegene wat die erotiese religieus vier juis tot die erotisering van die werkliheid bydra en die negatiewe verminder. Juis daarom moet die erotiese as religieus gesien word, aangesien dit in die seksuele nie slegs om 'n egoïstiese selfbevrediging behoort te gaan nie, maar ook om 'n positiewe inspuiting in 'n werklikheid wat nog in vele opsigte ontdaan is van liefde. Deur seks moet God dus gedien word. Om dus 
in die naam van God seks as "sondig, vleeslik en vieslik" te beskou is, (spreekwoordelik gesê) die grootste truuk in die duiwel se boek.

\subsection{Jesus van Nasaret en die seksuele}

Die ongekende gewildheid van die boek The Da Vinci Code van Dan Brown (2003) is ' $n$ teken daarvan dat die moderne mens belang stel in Jesus van Nasaret se siening en belewenis van die seksuele. Die boodskap van die boek is dat Jesus heel waarskynlik getroud was en kinders gehad het, maar dat die kerk hierdie feit (as gevolg van die kerk se negatiewe opvatting oor die seksuele en op grond van die geloof in Jesus se goddelikheid) versluier het. Hierdie idee (dat Jesus getroud was) het natuurlik ook gefigureer in Kazantzakis se roman, The last temptation of Jesus Christ (waarvan myns insiens een van die beste Jesusfilms gemaak is, maar wat steeds nie in SuidAfrika in 'n teater vertoon mag word nie). Natuurlik moet die genre van die boek en film deeglik verreken word en kan hierdie romans nie op sigself as historiese getuienis ten opsigte van Jesus se seksualiteit geld nie.

Hierdie besondere belangstelling in Jesus se seksualiteit kan moontlik veklaar word as 'n uitvloeisel van die moderne mense se begeerte om in harmonie te kom met hulle eie seksualitiet en om laasgenoemde positief te evalueer. Indien Jesus van Nasaret (wat dan 'n volmaakte mens sou wees) seksueel was, dan help dit om die eie seksualiteit sonder skuldgevoelens te erken, te aanvaar en te waardeer.

Daar kan moontlik 'n saak uitgemaak word dat Jesus wel getroud was (nie om rede Brown se teorie nie), maar omdat die rabbi's in sy tyd as 'n reël getrou het. Alhoewel moontlik en selfs waarskynlik, kan ons egter geensins 'n finale gevolgtrekking maak nie. Ons het gelukkig nie hierdie inligting nodig om te weet of hy 'n seksuele wese was nie. Want laasgenoemde kan ons wel met 'n hoë mate van sekerheid beweer, omdat hy 'n volkome mens was (vgl ook die werke van Phipps 1971; 1973).

Oor Jesus se eie siening oor die seksuele is ons wel beter ingelig. Hierdie siening van Jesus is belangrik vir veral Christene wat aan die seksuele sy regmatige plek wil gee as deel van hulle godsdiens, juis omdat hulle steeds eeue gebuk gaan onder die afkraking van die seksuele wat, nie by Jesus nie, maar by Paulus begin het ( 1 Kor 7 ).

Paulus se siening van die seksuele verskil van dié van Efesiërs 6 waar seks in die man-vrou verhouding as 'n religieuse misterie geteken word ( $\mathrm{vgl}$ hierbo). In 1 Korintiërs 7 kry ons 'n beredeneerde siening van Paulus oor die seksuele wat tot vandag toe nog verantwoordelik is vir die gangbare Christelike moraal oor die seksuele. Paulus se siening kan heel waarskynlik outobiografies verklaar word (vgl sy verwysing na die "doring aan sy vlees" en 


\section{Eros as godsdiens (of die religieuse viering van seks)}

sy wens dat almal soos hy was wat die gawe van onthouding het). Volgens Paulus is om nie te trou nie die ideaal, maar word die huwelik wel toegelaat ter wille van die swakkes wat van begeerte brand. Dit is duidelik die mindere opsie.

Paulus se siening word hier kortliks saam met dié van Jesus van Nasaret genoem aangesien laasgenoemde as teenvoeter ingespan moet word om die negatiewe van Paulus se siening teen te werk. Die religieuse viering van die seksuele vereis dat in die Christendom besef word dat dit 'n fout was om vir Paulus se standpunt te kies en die siening van Jesus van Nasaret te verwaarloos.

Dat die Christendom deur die eeue vir Paulus gekies het in plaas van Jesus kan toegeskryf word aan 'n streng wettiese kultuur wat nie daarin kon slaag om sy eie seksualiteit na waarde te skat en te vier nie. Reeds voor die tyd van Jesus het die beskouing begin posvat dat seks en godsdiens teenoorgesteldes in plaas van verlengstukke van mekaar is. Voorbeelde van sodanige wettiese kultuur is dat 'n onegte kind as sondaar gereken is en dat 'n vrou wat menstrueer onrein was.

Wat verder moontlik bygedra het tot die voorrang van Paulus se siening in die kerkgeskiedenis, is die feit dat sy opvattinge in 1 Korintiërs 7 as 'n deurlopende argument aangebied word, terwyl dié van Jesus as brokstukkies verspreid in die Evangelies voorkom. Jesus se siening verskil egter grootliks van dié van Paulus en diegene wat hulle seksualiteit wil aanvaar en religieus wil vier, kan grootliks baat (en bevryding!) daarby vind deur Jesus se houding, dade en sienings onder die loep te neem. Naas die moontlikheid dat hy self getroud was, kan die volgende aspekte genoem word.

- Nêrens degradeer Jesus die seksuele nie (ook beslis nie in Matt 19:1-3 nie).

- Omdat Jesus volkome mens was, was hy ook seksueel, tensy seks as sonde gesien word, wat Jesus nie doen nie.

- Jesus is pro-huwelik (Joh 2) en teen egskeiding gekant en motiveer sy standpunt deur 'n eksplisiete verwysing na die seksuele (Matt 19:3-6; Gen 2:24).

- Jesus het 'n besondere verhouding met vroue gehad. Hulle volg hom saam met die dissipels, salf sy voete (met erotiese konnotasies, vgl Luk 7:36-50), sit aan sy voete en luister (Luk 10:38-42), is teenwoordig by sy kruisiging en is eerste by die leë graf. Van besondere betekenis 
is sy verhouding met Maria Magdalena volgens die Johannesevangelie (Joh 20:17). Na die opstanding sê hy vir haar dat sy hom nie moet "aanraak" of "vashou" nie (soos blykbaar haar gewoonte was). Dit is veelseggend dat die Griekse woord wat hier gebruik word (haptomai) ook gebruik word vir seksuele kontak en dat laasgenoemde dus nie hier uitgesluit is nie.

- Jesus het deurgaans simpatie getoon met diegene wat die kontemporere seksuele wette oortree het, soos byvoorbeeld prostitute (Luk 7) of vrouens wat in owerspel betrap is (Joh 8:1-11). Hy staan bekend as ' $n$ vriend van hoere en tollenaars en gaan selfs sover om te verklaar dat die hoere en die tollenaars die Fariseërs voorgaan in die koninkryk van God (Matt 21:31).

- Jesus was na alle waarskynlikheid 'n "onegte" kind. Laasgenoemde blyk uit die strekking van Matteus 1:18-25 en word met oortuiging beredeneer deur Van Aarde in sy boek Fatherless in Galilee (2001:7275;119-134; vgl ook Schaberg 1987). Juis as gevolg hiervan toon hy deernis met die mensdom en veral kinders. In 'n sekere sin moet ons dankbaar wees vir die berigte oor die maagdelike geboorte in die Bybel, want dit is die enigste manier hoe die evangeliste as kinders van hulle tyd aan ons kon kommunikeer dat Jesus 'n onegte kind was. Wie hieraan aanstoot neem, verag onegte kinders as "hoerkinders" (soos reeds in Jesus se tyd gebeur het) en openbaar 'n houding van gevoelloosheid wat direk ingaan teen Jesus se houding van deernis en empatie. Die implikasie hiervan is dat sogenaamde "onegte" kinders vandag eerder met ekstra deernis omarm behoort te word.

Alhoewel ons nie volledig ingelig is oor Jesus se persoonlike seksuele lewe nie, kry ons wel 'n kykie op die feit dat hy nie 'n a-seksuele wese was nie en dat hy seksualiteit in 'n positiewe lig beskou het. Jesus het seksualiteit volledig erken as komende van God en het dit nie los van die liefde gesien nie. Wat ons verder positief kan sê, is dat indien Jesus wel as onegte kind gebore was, getroud was of in 'n liefdesverhouding met Maria Magdalena gestaan het, dit geensins afbreuk doen aan sy karakter nie. Inteendeel: wie dit skokkend vind glo ten diepste seks is sonde en beledig Jesus.

\section{WENKE VIR DIE RELIGIEUSE ONTGINNING VAN DIE SEKSUELE}

Om die religieuse aard van die seksuele te ontwikkel en te ontgin, kan sekere houdings ingeneem word en handelinge met simboliese waarde met vrug 


\section{Eros as godsdiens (of die religieuse viering van seks)}

gebruik word. Die volgende is voorstelle wat 'n mens se seksuele en godsdienstige ervaring tot groter hoogtes kan voer en uiters dankbaar kan maak vir die voorreg om te kan lewe. Hierdie ontginning staan nie teenoor die proses van heiligmaking nie, maar vorm 'n integrale deel daarvan. Enige siening van heiligmaking wat die seksuele verontagsaam, is ook ten diepste eensydig en gebrekkig. ${ }^{7}$

- Die skaamtelose erkenning en aanvaarding van die eie seksualiteit. Net soos mens nie skaam vir jou religieuse aard en opvattinge hoef te wees nie, so eer mens ook God deur jou eie seksuele aard te erken en dankbaar te aanvaar.

- Seksuele omgang in die vrye natuur (bv in die berge, bos, langs die see of onder 'n waterval) kan byvoorbeeld die dimensie onderstreep dat mens in die beoefening van die seksuele deel is van God se mooiste skepping, vry en taboeloos. So teken Hooglied dit telkemale en so was dit Adam en Eva se geluk in die Paradys. Dis betekenisvol dat in die Genesisverhaal sonde juis plaasvind wanneer dit nie meer so gesien word nie; wanneer ander selfsugtige a-religeuse en nieseksuele optrede die kaarte deurmekaar krap.

- Die bed as altaar. Die seksuele daad se religeuse aard word verhoog indien dit met rituele gepaard gaan. ' $n$ Bed of tafel kan speels maar heel ernstig ingerig word as 'n altaar met byvoorbeeld kerse en wierrook wat gebrand word. Om dit te doen is alles behalwe godslasterlik, maar word juis gedoen om God te eer deur die religieuse aard van die seksuele te erken.

- Ontginning van die seksuele as 'n vorm van aanbidding. Dit kan gedoen word deur seksuele posisies te eksploreer wat met gebedshoudings ooreenstem, en dit as sodanig te waardeer. So gesien is cunnilingus en fellatio op hulle beste vorme van aanbidding.

- Volgehoue seksuele meditasie. Seksuele gedagtes en denke as deel van die liefde moenie vermy of probeeer onderdruk word nie, maar vrye teuels gegee word. Omdat laasgenoemde in die westerse Christendom so onderdruk is, kan ander godsdienstige tradisies (bv die

\footnotetext{
${ }^{7}$ So byvoorbeeld bespreek die boek van Berhouwer, Geloof en heiliging (1949), glad nie die seksuele nie en word die indruk gewek dat dit aangeleenthede behels wat teenoor mekaar staan. Dieselfde geld vir sy boek, Die mens het beeld Gods (1957), ten opsigte van die imago Dei (vgl hierbo).
} 
Kamma Sutra van die Hindoeïsme, die Tantra Boeddhisme en die Yin en Yang van die Toaïsme) met vrug ondersoek word om hierdie dimensies vir die Christendom terug te wen (vgl Wik \& Wik 2005:113130; LaChapelle 1999:110-161). Die gesamentlike bestudering van gepaste literatuur oor seksuele tegnieke fasiliteer ook die denke oor die seksuele (vgl bv Westheimer 1994; Boteach 1999; Pauli 2002; Gray 1996; Van de Velde 1967; Copelan 1972).

- Die beoefening van die seksuele spel deur klassieke, veral religieuse musiek as agtergrond te speel (bv die Messias van Händel en Beethoven se Ode aan die vreugde en vele ander). So word die seksueel-religieuse ervaring gevoer tot groter spirituele hoogtes.

- Soms kan dit pornografies wees om te sê pornografie is pornografie. Daar bestaan 'n gesonde stimulering van die seksuele as religieuse deur gepaste erotika en die kunste (skilderkuns, letterkunde en film). Dit kan beteken die waardering van naakte skilderye, erotiese verhale, asook erotiese films. ${ }^{8}$

- Die aktiewe deelname aan die seksualisering van die samelewing beteken om nie die seksuele in isolasie te sien nie, maar God te dien deur die samelewing deur die seksuele te dien. Hierdie aspek is uiters belangrik en word derhalwe onder 'n aparte volgende hofie bespreek.

\section{DIE SEKSUALISERING VAN DIE SAMELEWING}

Die erotiese liefde vir die geliefde moet uitkring na liefde vir die samelewing, die land, die aarde en die kosmos. Die seksualisering van die samelewing beteken dat die samelewing weer waardes sal ontwikkel en sal begin besef waarom dit eintlik in die lewe gaan. Volgens Fromm (1957:72-89) behoort mens nie slegs op egoïstiese wyse op die geliefde alleen te fokus nie maar moet mens die mensdom deur die geliefde liefhê. Dit beteken die bevordering en deursuring van die samelewing met deernis, barmhartigheid, sorg en liefde

\footnotetext{
${ }^{8}$ Wat pornografie is en wat nie, is 'n uiters subjektiewe saak en lê inderdaad "within the eye of the beholder". Wat wel gesê kan word is dat pornografie niks met naaktheid te doen het nie (om naaktheid te degradeer is eerder pornografies). Pornografie het (in die lig van ons tema) eerder te make met die skeiding van die seksuele en die religieuse. D H Lawrence (aangehaal in Brink 1975:119) druk dit as volg uit: "Genuine pornography is almost always underground, it doesn't come into the open. In the second place, you can recognize it by the insult it offer, invariably, to sex, and to the human spirit. As soon as there is sex excitement with a desire to spite sexual feeling, to humiliate it, and degrade it the element of pornography enters." Vir my persoonlik is die uitbeelding van Amerikaanse rofstoei op televisie 'n blatante voorbeeld van ongewenste pornografie.
} 


\section{Eros as godsdiens (of die religieuse viering van seks)}

wat veral deur die beklemtoning en die religieuse viering van die erotiese teweeggebring word. Die regte religieuse siening en bevordering van die erotiese help as 'n teenmiddel teen verdraaide waardes in ons sogenaamde beskawing waar tegnologiese vooruitgang, rykdom, politieke magsug, konflik en die wenmotief die botoon voer (vgl Marcuse 1972:142-157).

Die religieuse belewenis van die seksuele is so groots, aangenaam en kongruent dat indien mense daaraan deel het, hulle besef dat die waardes van die moderne samelewing verdraaid is en die mensdom groot pyn en leed verskaf. Die religieuse belewenis van die seksuele ontmasker die rigtingloosheid van die moderne samelewing as 'n gejaag na wind en die besef van die sinloosheid daarvan dryf die mens terug na die erotiese om laasgenoemde op steeds hoër hoogtes religieus te vier.

Hoe word sodanige seksualisering van die samelewing bewerkstellig? Slegs enkele aspekte word hier genoem.

- Stry vir vrouens en ander onderdruktes. Die intense emosionele gevoel wat deel uitmaak van ware seksualiteit, moet oorgaan na die gevoel van empatie of medelye wat dade van solidariteit en barmhartigheid ten grondslag lê. Nooit behoort gevoelens van solidariteit egter oor te gaan in geweld nie, want geweld staan lynreg teenoor die seksuele.

- Die onselfsugtige beoefening van mededeelsaamheid, veral van besittings. Dat seks naak beoefen word het hier 'n ongekende simboliese waarde. Dit beklemtoon die heiligheid daarvan en is 'n aanduiding dat om te wees (bestaan, lewe, vgl Fromm 1979) veel belangriker is as om te besit. Baie keer waarborg die rykdom van rykes stres en seksloosheid. Aan die ander kant maak die seksuele belewenisse van armes dikwels hul armoede 'n ligter las en daarop is die rykes eindeloos jaloers.

- Bevordering van deernis, begrip en liefde wat op die kontinuum van die seksuele daad behoort te lê. Konkrete dade van barmhartigheid na seksuele omgang kan gedoen word uit dankbaarheid vir die wonderlike belewenis van die seksuele en onderstreep dat die seksuele aktiwiteit self liefde is (deur bv direk na die liefdesspel iemand wat eensaam is te bel, of te besoek). ${ }^{9}$

\footnotetext{
${ }^{9}$ Sommige jong getroude pare wat nog nie kinders het nie neem byvoorbeeld pleegkinders uit kinderhuise elke tweede naweek in. Mag sulke pare se sekslewe tot op hul oudag floreer!
} 
- Die keersy van bogenoemde is die openlike afkeer van ongekontroleerde ambisie, magsug, geweld en oorlog (vgl die moontlikhede wat Chopra 2005 noem in hierdie verband). Magsug, geweld en oorlog funksioneer dikwels as 'n substituut vir 'n onvervulde sekslewe en moet as sulks ontmasker word.

- As jy na jou kinders kyk, dink terug aan en koester die dag toe hulle verwek is. Positiewe ouerlike seksuele voorligting is broodnodig. In plaas daarvan om kinders voortdurend teen die seksuele te waarsku, moet hulle eerder daarop gewys word dat die seksuele 'n religieuse dimensie het: indien dit ingeboet word, verloor die seksuele en die lewe as sodanig sy kwaliteit.

- Grootouers het ook 'n belangrike rol te speel in die huwelike van hulle kinders wat self kinders het. Hulle kan hulle kinders aanmoedig om tye weg te gaan en hulle seksuele verhouding te ontgin. Hulle kan help deur byvoorbeeld die kleinkinders (wat dikwels figureer as jakkalsies wat die wingerd verniel) op te pas. Vriende en kennisse kan mekaar ook so help. Laasgenoemde is die beste teenmiddel teen gebroke huwelike wat families uitmekaar ruk en die samelewing benadeel.

Kortom: om die seksuele te bevorder en religieus te dui is om hierdie wêreld 'n beter plek te maak en sodoende God se wil te laat triomfeer.

\section{TEN SLOTTE}

Wat hierbo gesê is verteenwoordig maar 'n fraksie van wat ten opsigte van hierdie onderwerp moontlik is. Dit is as blote akademiese diskoers sinloos indien dit nie in die praktyk nagestreef word nie. As die groot kriterium van die liefde geld is die moontlikhede vir kreatiwiteit eindeloos.

Mense dink nie heeltemal dieselfde oor die seksuele nie en hoef ook nie. Dit sou uiters vervelig wees en opsigself onseksueel. Wat gesê is, is wel bedoel as 'n uitnodiging aan die leser om seksueel en religieus bevry te word, of die reeds verworwe vryheid te koester en tot groter hoogtes te voer. Want vryheid is iets wat verloor kan word. Mag verdere lees en denke, liewe leser, dus nie 'n terugkeer wees na moralisering nie, maar lei tot die nog wyer oopmaak van die horisonne. Ubi caritas et amor, ibi Deus est. Waar liefde is, is God. 


\section{Eros as godsdiens (of die religieuse viering van seks)}

\section{Literatuurverwysings}

Bataille, G 1962. Eroticism. London: Penguin Books.

Berkouwer, G C 1949. Geloof en heiliging. Kampen: Kok.

Berkouwer, G C 1957. Die mens het beeld Gods. Kampen: Kok.

Bonhoeffer, D 1995. Een woord voor elke dag. Ten Have: Baarn.

Boteach, S 1999. The Jewish guide to adultery: How to turn your marriage into a delicious affair. London: Hodder \& Stoughton.

Brown, D 2003. The Da Vinci code. London: Corgi Books.

Breytenbach, B 2000. Lady one (99 liefdesgedigte). Kaapstad: Human \& Rousseau.

Brink, A 1975. Aspekte van die nuwe prosa. Pretoria: Academica.

Carr, D 2003. The erotic word: Sexuality, spirituality and the Bible. Oxford: Oxford University Press.

Chopra, D 2005. Peace is the way: Bringing war and violence to an end. London: Rider.

Clines, D J 1995. Interested parties: The ideology of writers and readers of the Hebrew Bible. Sheffield: Sheffield Academic Press.

Copelan, Rachel 1972. The sexually fulfilled man: 5 sensual steps to becoming her greatest lover. New York: New American Library.

Dorey, P J 2003. Genesis 2:24 - Locus classicus vir monogamie?: 'n Literêrhistoriese ondersoek na perspektiewe op poligamie in die Ou Testament. PhD-proefskrif, Universiteit van Pretoria.

Du Toit, A B 2007. Maar die grootste hiervan is die liefde - oor homoseksualiteit in Romeine 1, in Vos \& Human 2007:161-171.

Foucault, M 1978. The will to knowledge: The history of sexuality. London: Penguin Books.

Freud, S [1905] 1961. Drei Abhandlungen zur Sexualtheorie. Frankfurt am Main: Fischer Taschenbuch Verlag.

Fromm, E 1957. The art of loving. London: George Allen \& Unwin.

Fromm, E 1979. Haben oder sein: Die seelische Grundlagen einer neuen Gesellschaft. Munchen: Deutscher Taschenbuch Verlag.

Gray, J 1996. Mars and Venus in the bedroom: A guide to lasting romance and passion. London: Vermillion.

Haspel, M 2004. Christian sexual ethics in a time of HIV/AIDS - A challenge for public theology. Verbum et Ecclesia 25(2), 480-501.

Janson, M 1995. God se "ja" vir seks. Pretoria: Aktuapers.

Kretzschmar, L 2001. Sexual ethics: Only study guide for CGM302-T. Pretoria: University of South Africa.

Kroeze, J H 1970. Die Bybel en seks. Johannesburg: Boekhandel De Jong.

LaChapelle, D 1999. Heilige Erde, Heiliger Sex: Band 3: Der Himmel auf Erden. Saarbrücken: Neue Erde.

Landman, C 1999. Vryers en vennote. Kaapstad: Struik Christelike boeke.

Marcuse, H 1972. Eros and civilization: A philosophical inquiry into Freud with a new preface by the author. London: Abacus.

Müller, J C 2007. Seks en die huwelik: Evangelie in plaas van wet, in Vos \& Human 2007:372-383.

Nelson, J B \& Longfellow, S P (eds) 1994. Sexuality and the sacred: Sources for theological reflection. London: Westminster. 
Nygren, A 1969. Agape and eros. New York: Harper \& Row.

Otto, E 2007. Homoseksualiteit in die Ou Nabye-Ooste en Ou Testament, in Vos \& Human 2007:58-66.

Pauli, M 2002. Spiritual sex. London: MQ Publications.

Phipps, W 1971. Was Jesus married? New York: Harper \& Row.

Phipps, W 1973. The sexuality of Jesus. New York: Harper \& Row.

Pope, M 1977. Song of songs: A new translation with introduction and commentary. New York: Doubleday.

Schaberg, J 1987. The illegitimacy of Jesus: A feminist theological interpretation of the infancy narratives. San Francisco, CA: Harper \& Row.

Steyn, G J 2007. Riglyne vir die verstaan van homoseksualiteit binne die konteks van die Nuwe Testament, in Vos \& Human 2007:172-204.

Thielicke, $\mathrm{H}$ 1964. The ethics of sex. Cambridge: James Clarke.

Van Aarde, A G 2001. Fatherless in Galilee: Jesus as child of God. Harrisburg, PA: Trinity Press International.

Van de Velde, T 1967. Die vollkommene Ehe: Eine Studie über ihre Physiologie und Technik. Stuttgart: Albert Müller.

Vos, C \& Human, D (reds) 2007. Liefde is die grootste: Oor erotiek en seksualiteit. Pretoria: Protea Boekhuis.

Walsh, C E 2000. Exquisite desire: Religion, the erotic and the Song of Songs. Minneapolis, MN: Fortress Press.

Westheimer, R 1994. The family encyclopedia of sex. Shaftesbury: Elements Books.

Wik, M \& Wik, S 2005. Beyond Tantra: Healing through Taoist sacred sex. Findhorn: Findhorn Press.

Wilber, K 2000. Sex, ecology and spirituality: The spirit of evolution. Boston, MA: Shambhala Publications. 